\title{
Religion Intervention in Character Building of University Students
}

\begin{abstract}
Said Hariadi
Universitas Negeri Gorontalo, Gorontalo, Indonesia

*Corresponding author.Email: hariadisaid_gto@rocketmail.com

ABSTRACT

This study is intended to examine the impact of the religion intervention in character building of university students. The subject involved as many as 112 students in the department of physical and health education, Faculty of Sports and Health, Universitas Negeri Gorontalo (UNG), from a total of four classes. The research Religion intervention served a purpose as the research design; it started prior to learning activities or classes. The interventionwas divided into two, e.g., religion intervention (ta'limor Islamic forum) and place of worship intervention (mosque).The first intervention (ta'lim) was conducted before dhuhr prayer time on which all of the students attended an Islamic forum to gain in-depth insight regarding the importance of worship. Commendable natures, e.g., discipline, obedience, leadership, cooperation, mutual respect, and loyalty to the group, as well as other goodnatures. The results reveal that the religion intervention constructs three characteristics of the students, namely normative, doubtful, and over-confidence. The percentage of these characteristics are students with normative character $69.23 \%$, students with doubtful character $16.27 \%$, and students with over-confidence character $14.45 \%$. The above findings prove that the religion intervention is fruitful in building the students' character.
\end{abstract}

\section{Keywords: Intervention, Religion, Character Building.}

\section{INTRODUCTION}

Promoting a religious atmosphere is able to change the lifestyle of thecommunity including academic community, i.e., students. Environmental condition impacts on the appearance of an individual or groups significantly. In a study, the environment plays amajor role in relieving stress and mental exhaustion in order to improve one's feeling and cognition. In other words, environmental factors must be taken into account in coping with physic problems. Four principles of environment, such as 1) moving away from the everyday environment allows people to free their minds from the attention they are aiming for, 2) this is related to what the individual wants to do and whether the environment is supportive of accomplishing such a target, 3 ) the environmental appeal where the person resides, and 4) aspects related to the extent of the feeling in understanding that a person is in another dimension as a whole. These indicate that the environment is possible to change a person; for example, a person considers him or herself able to do something different in a different environment.

Some environmental studies report that natural environment is different with anartificial environment. A situational atmosphere will be promoted once the natural environment provides a situation as it is. One of the artificial environment is a mosque on which the environment offers an alternative of resources for its visitor, i.e., students. Experts in environment point out that mosque, for some people, is considered as a place where they can experience a spiritual rejuvenation [1].

The results were seen in show that a worship place can serve a purpose to facilitate people who seek for tranquility and inner peace to cope with mental fatigue [2]. This is because usually, the design of a mosque has more than one entrance and, therefore, the circulation is more open than other designs. Furthermore, the design of a mosque is often sociopetal, a design that promotes social interaction by which the place eases every individual in interacting with others, even though some are closed communications against other groups. a mosque can be built next to another mosque to promote good interaction. It is in line with what Rasulullah did with his companion in their efforts to disseminate the teachings of Islam in theMiddle East. At that time, a mosque serves a purpose as a place to discuss the attempts in the struggle of disseminating Islam.

In response to the above nuance, the main objective of visiting mosque is a restorative (being away from daily routines) and spiritual aspects [3]. It can be assumed that a worship place is similar from one to another, meaning that a mosque can serve as a place for experiencing spiritual rejuvenation including university students. 
University students are often preoccupied with activities that require lots of energy. The students need energy for several processes, e.g., thinking, organizing theschedule, and decision-making. Furthermore, the main activities of university students revolve around attending the class, working on assignments, participating in a classroom discussion, and other extra-curricular activities. Due to exhausting and time-consuming academic activities, the university students often end up with physical and psychological fatigue. To cope with such issues, most of the students spend their time to take a nap, eating in thecafeteria with friends, or taking some rest in a classroom. "Points out that there are other students who opt for spending time in a place where they can restore their energy, to experience a psychological rejuvenation, i.e., spending time in a mosque" [3].

The above situation implies that people can benefit much from a mosque if they adjust themselves to discipline lifestyle. Praying in congregation is able to develop commendable natures, e.g., discipline, obedience, leadership, cooperation, mutual respect, and loyalty to the group, as well as other good natures. This can be conceptualized since every movement in salah (Islamic pray) comprise a mixture of beneficial movement and model.

"one can gain beneficial information regarding education and aesthetic if he or she observes the way Rasulullah SAW pray and the way he concerns the procedures of praying in congregation" [4]. This is corroborated by the warning of Rasulullah SAW not to precede the Imam in the prayer movement, as contained in his saying: "do not you precede me (imam prayer) in ruku' sujud, standing,andsalam, then the commanded charge in this hadith will guarantee theunity of prayer movement". The unity of the prayer movement and the concern of the practitioners of prayer to keep following the priest will be able to create conditions of leadership, obedience, and to be loyal to the people in praying in congregation.

The unity of ruku', sujud, and other movements can create aesthetic elements similar to those created by artists that is reflected through a series of movements and formations by a large group of people, standing in a row, or in other formations, e.g., in form of a circle, a square, and a long row.

Furthermore, by paying attention to every movement in salah, one may see the explained formations representing that the people who pray in congregation form a circle-like shape (ta'lim) or a square that resembles the area surrounding Kaaba in Masjidil Haram. This shows that Islam has first discovered unique formations; these formations also possess other uniqueness.

Such uniqueness can be seen in the implementation of prayer, people who just come can immediately follow the prayer even though the prayer has been started and in different rakaat without reducing the movement in salah. Furthermore, this example cannot be seen in other arts in a sport. Such example regarding the group is only for a particular time or period; this is different from performing salah.
This study aims to find out how much the influence of Ta'lim before the lecture begins towards the change of students' characters. To participate in Ta'lim, students do not need costs and energy due to the location of the mosque which is on campus where they study, meaning that there is no reason for them not to attend the Ta'lim in the mosque that is close to them. Meanwhile, the Ta'lim material has been designed and planned according to the needs (problems) of the students.

\section{METHOD}

This study employed qualitative method intended to explore students' potential (faith) at Department of Physical and Health Education, Faculty of Sports and Health UniversitasNegeriGorontalo. This study involved 112 fifth semester students at the age of 19-22 years old which are divided into four different classes. The research subject was the active students who were recorded in the academic information system of UniversitasNegeriGorontalo. Psychologically, at the age of 19-22 years old, students tend to start thinking carefully about something they want to achieve, so that they have a realistic view of themselves and the environment surrounding them

The data were collected from students' self-report in which it gave flexibility to the students to assess themselves. The data were further analyzed by using Interpretative Phenomenological Analysis (IPA) technique. IPA analysis technique is intended to explore the subjective experiences of individuals based on their point of view. The researcher as a lecturer of psychology subject attempts to reveal students' experience in attending Ta'lim held at the mosque on campus where they are studying.

The research results reveal thatTa'limand mosqueinterventions are not only limited to religious rituals but also become a place to shape students' character to be religious servants. The results show that Ta'limand mosque interventions are able to generate three kinds of students' characters; normative, doubtful and overconfident.

There are $69.23 \%$ of students with the normative character in which they appear with the norm according to the right circumstances. The students with this character are treating themselves as it should be, or in other words, they are fair towards themselves. Regarding the assessment, they assess themselves in line with their ability. They assess themselves completely according to the approved assessment criteria.

Further, there are $16.27 \%$ of students with the doubtful character. They are not able (not brave) to reveal the truth and are too doubtful in giving their self-assessment. The students with this character are not able to assess themselves, although the criteria have been accepted. The given value is far from what is observed and assessed by the lecturer who also assesses them. The students tend to be doubtful about their ability, although their performances are good and they master the paper that they explain. 
The last character is over-confident that it arrives at the percentage of $14.5 \%$. The students with this character do not care about their surroundings (classmates and lecturers). They treat themselves based on their feeling without concerning the approved assessment criteria before the lecture begins. This means that the students assess themselves according to their desire, even though they realize that their performance is not actually perfect.

\section{RESULT}

The results reveal that all students involved in this study show different potentials with different values. In general, the results indicate that students who become the object of this study are in three different groups, namely; normative character, doubtful character, and overconfident character groups. Group differences seem to imply that the students have different potentials; some were born with a normative potential, some were born with a doubtful potential, and some were born with an overconfident potential. It is easier for students with normative potential to understand themselves from various perspectives as well as to adapt to the environment where they join. Ta'limintervention can enlighten students' mind and heart, particularly in religious knowledge. The content of Ta'lim in the form a metaphor is able to doctrine people's mind. For instance, Ta'limabout the importance of studying as in QS Al-Mujadilah verse 11 which states that those who seek knowledge will be raised in degree than others. In order to understand this verse, the researcher provides an illustration to the students such as a Regent who can lift $50 \mathrm{~kg}$ of rice only with his index finger. It is because his degree has been raised so that everyone will obey his order. Therefore, it is not surprising that he just points at few people to lift the rice sack.

Talking about mosque, it is able to bring peace to its visitors/worshippers. It means that a mosque can change one's behavior as in line [5]. This happens because a mosque can bring peace and comfort to the worshipper due to its spiritual value. By visiting a Mosque, the visitors' mind will be calm and peaceful as well as they will be enthusiastic to do their activities. The nuance of mosque always presents a positive mind, so that some students will feel calm and peaceful when they are in the mosque.

Various problems faced by the students merge into one part. Thus, it is easy to be overcome. Mosque with all its advantages is able to unite all elements inside it. On that ground, any problem if solved in the mosque will be overcome with peace. This is what Rasulullah SAW always does with his companions if any problems need to be solved. Mosque is not merely a worship place, yet it can present a spiritual feeling. Many students feel enthusiastic after performing $w u d u$ (Islamic procedure for washing parts of the body, a type of ritual purification). Even some of them feel that they have a new life after performing $w u d u$, meaning that Salah (a physical, mental, and spiritual act of worship) and listen to Ta'limcan change everything.

Students with a doubtful character indicate that they have not been exploring what is really going on around them. Tak'lim that they often attend before praying $\mathrm{Zuhr}$ has not been able to make them sure about something. Whereas, QS Al-Baqarah verse 2 states that there is no doubt, a guidance for those conscious of Allah. Attending Ta'lim is one of the signs that students are in a state of piety. Being in a mosque is also a sign that students are fulfilling their obligation to Allah SWT. However, for students who are still in doubt, all the advantages obtained from Ta'lim and Salah in mosque have not been able to change their doubtful character. Interview result by friends of the students with doubtful character reveals that they are not in doubt about the content of the Ta'lim and the atmosphere in the mosque, yet they cannot negate their feeling of doubt. Therefore, after the Ta'limis finished and the mosque atmosphere does not longer exist, the students are still in doubt. The approved assessment cannot be applied in their life on campus.

Students with an over-confident character are those who have their own thoughts regarding the assessment. Although the assessment criteria have been designed in such a way, they still ignore it. Ta'lim containing honest life advice and other essential things cannot make them aware of the truth. Similarly, religious nuances in a mosque seem to have no effect on their behavior. This group is more enjoying with themselves. The expectation of a meaningful life is like moving away from them. The aura of the mosque that offers peace and honesty does not mean to them, indicating that this group becomes a challenge in applying a religious life.

\section{CONCLUSION}

The energy wasted in the lectures does give an impact on students' physical and psychological aspects. Physical fatigue can essentially be overcome by adequate rest, meaning that it is easy for them to deal with their physical fatigue. On the other hand, psychological fatigue needs a special treatment. This is because psychological fatigue can only be observed by one's behavior. Accordingly, the recovery of psychological fatigue requires a special treatment, such as intervention. The result shows that religion intervention can create students with an Islamic character.

\section{REFERENCES}

[1] Packer, Bond, N, "Museums as restorative environment," Curator; J. Meseum. 53(4), 421456. 2010.

[2] Aynsley, R, "Natural Ventilation in Passive Design," BEDP; Environment Design of Environmental Psychology, 41(2), 1-9. 2007.

[3] Nurhafifi, M., Qaryna, A., Nabila, A., Syahrain., N.N., \& Mahudin, N, "The Masjid as a Restorative Environment: a Case Study of Masjid Sultan Haji Ahmad Shah," IIUM; Seminar Proceeding, UMRAN. 2013.

[4] Jalal Syafi'I, "Dahsyatnya Gerakan Shalat, tinjauan Syariah \& Kesehatan [The Advantages of Movement of Salah, an Overview from the 
Perspective of Sharia and Health," Jakarta; Gema Insani. 2009.

[5] Kaplan, R., \& Kaplan, S, "Toward a synthesis: The experience of nature: A psychological perspective," UK; Cambridge University Press. 1989.

[6] Al-Qur'an 